\title{
POP-UP Book Daur Hidup Hewan
}

\section{Luh Putu Eva Novita ${ }^{1 *}$, I Made Tegeh ${ }^{2}$}

1,2 Universitas Pendidikan Ganesha, Singaraja, Indonesia

\section{ART ICLE INFO}

\section{Article history:}

Received June 04, 2021

Revised June 05, 2021

Accepted July 14, 2021

Available online July 25, 2021

Kata Kunci:

Pop-Up Book, Daur Hidup Hewan

Keywords:

Pop-Up Book, Animal Life

Cycle

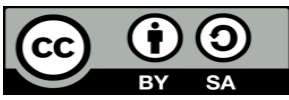

This is an open access article under the CC BY-SA license.

Copyright (C) 2021 by Author. Published by Universitas Pendidikan Ganesha.

\begin{abstract}
A B S T R A K
Kurangnya kreatifitas guru dalam mengembangkan media pembelajaran, khususnya pada mata pelajaran IPA yang menyebabkan kegiatan pembelajaran tidak berjalan dengan optimal sehingga menyebabkan beberapa siswa belum mencapai nilai KKM pada nilai kompetensi pengetahuan IPA. Oleh karena itu, perlu adanya pengembangan media pembelajaran yaitu media Pop-Up Book. Penelitian ini bertujuan untuk mendeskripsikan proses pengembangan media pembelajaran Pop-Up Book dan mengetahui validitas hasil pengembangan media pembelajaran Pop-Up Book pada mata pelajaran IPA. Subjek dari penelitian ini adalah pengembangan media pembelajaran Pop-Up Book pada mata pelajaran IPA, sedangkan objek dari penilitian ini adalah validitas media pembelajaran Pop-Up Book. Jenis penelitian ini adalah penelitian pengembangan yang menggunakan model ADDIE. Namun, penelitian ini hanya dilaksanakan sampai tahap pengembangan saja, tahap implementasi dan evaluasi tidak dilaksanakan karena saat ini masih pandemi Covid-19. Penelitian pengembangan ini menggunakan metode kuesioner dengan menyebarkan lembar penilaian kepada responden yaitu ahli isi mata pelajaran, media pembelajaran, desain pembelajaran, praktisi, dan uji coba perorangan. Hasil penelitian menunjukkan bahwa media Pop-Up Book pada pelajaran IPA dikembangkan dengan menggunakan model ADDIE yaitu tahap analisis, perancangan, pengembangan, implementasi, dan evaluasi. Selain itu, hasil validitas media Pop-Up Book pada pelajaran IPA dinyatakan valid dari review para ahli dan pengguna dengan persentase hasil ahli isi mata pelajaran 93,3\% (sangat baik), ahli media pembelajaran 95\% (sangat baik), ahli desain pembelajaran 95,3\% (sangat baik), ahli praktisi 97,1\%, (sangat baik), dan uji coba perorangan 93,8\% (sangat baik). Dari hasil ini, media pembelajaran Pop-Up Book ini dinyatakan layak untuk digunakan karena memiliki kualifikasi yang sangat baik.
\end{abstract}

\begin{abstract}
A B S T R A C T
Lack of teacher creativity in developing instructional media, especially in science subject which causes learning activities not to run optimally, so that it causes some students to have not reached the minimum completeness criteria value on the science knowledge competency value. Therefore, it is necessary to develop learning media, namely Pop-Up Book media. This study aims for describing the steps of developing the Pop-Up Book media and to find out the validity results of the development of the Pop-Up Book media in the science subject. This type of research is development research using the ADDIE model. The subject of this study was the development of Pop-Up Book media; meanwhile the object of this study was the validity of the Pop-Up Book media. However, this research was only carried out until the development stage, the implementation and evaluation stages were not carried out because currently it was still the Covid-19 pandemic. This development research used a questionnaire method by distributing assessment sheets to respondents, namely the experts of subject content, learning media, learning design, practitioner experts, and individual trials. The results showed that the Pop-Up Book media in science subject was developed using the ADDIE namely the stages of analysis, design, development, implementation, and evaluation. In addition, the validity results of the Pop-Up Book media in science subject was stated valid from reviews by experts and users with the percentage of results from subject content experts 93.3\% (very good), learning media experts 95\% (very good), learning design experts $95.3 \%$ (very good), the practitioner experts $97.1 \%$ (very good), and the individual trials 93.8\% (very good). From these results, this Pop-Up Book media was stated feasible for use because it had very good qualifications.
\end{abstract}

\section{PENDAHULUAN}

Ilmu Pengetahuan Alam (IPA) merupakan salah satu mata pelajaran penting yang ada di sekolah dasar. IPA adalah pengetahuan yang berhubungan dengan fenomena alam tidak hanya kumpulan fakta dan konsep, tetapi juga tentang cara bekerja, cara berpikir, dan cara memecahkan masalah (Syawaludin et al., 2019). Ilmu pengetahuan alam juga diartikan sebagai ilmu pengetahuan tentang alam yang diperoleh berdasarkaan pengalaman manusia akibat interaksi dengan lingkungannya (Juniati \& Widiana, 2017). Pada mata pelajaran IPA memuat teori-teori alam yang dapat digunakan untuk menyelesaikan persoalan dalam kehidupan sehari-hari (Mustofa \& Syafi'ah, 2018). Ciri pokok pembelajaran IPA yaitu interaksi 
antara siswa dengan lingkungannya(Sugiarti \& Handayani, 2017). Pembelajaran IPA akan lebih bermakna jika proses pembelajara Pembelajaran IPA di SD dilakukan sendiri oleh siswa melalui penyelidikan sederhana, diskusi, dan pengamatan secara langsung bukan hafalan terhadap kumpulan konsep IPA, sehingga dengan kegiatan tersebut siswa mendapatkan pengalaman langsung. Dengan pembelajaran bermakna siswa akan mendapatkan pengalaman yang lebih banyak serta dapat mengembangkan social emosi(Bressington et al., 2018; Kostiainen et al., 2018). Tujuan muatan pelajaran IPA di SD/MI yaitu menumbuhkan keyakinan terhadap kebesaran Tuhan Yang Maha Esa atas keberadaan, keindahan, dan keteraturan alam ciptaannya; mengembangkan pengetahuan dalam bentuk rasa ingin tahu, sikap positif dan kesadaran tentang adanya hubungan yang saling mempengaruhi antara IPA, lingkungan, teknologi dan masyarakat; mengembangkan keterampilan proses untuk menyelidiki alam sekitar; memecahkan masalah dan membuat keputusan, serta meningkatkan pemahaman terhadap konsep-konsep IPA yang bermanfaat serta dapat diterapkan dalam kehidupan sehari-hari; meningkatkan kesadaran untuk selalu memelihara, dan menghargai lingkungan alam serta segala keteraturannya sebagai salah satu ciptaan Tuhan Yang Maha Esa; dan memperoleh bekal pengetahuan, konsep dan keterampilan IPA sebagai dasar untuk melanjutkan pendidikan ke SMP/MTs (Putra, 2017). Jadi, pembelajaran IPA akan memberikan manfaat yang sangat besar terhadap pembentukan pengetahuan siswa. Mengwujudkan pembelajaran IPA yang bermakna dibutuhkan media pembelajaran.

Media pembelajaran akan membuat materi yang bersifat abstrak menjadi lebih nyata. Penggunaan media secara kreatif dapat memperlancar dan meningkatkan efesiensi pembelajaran sehingga (Kurniawati \& Nita, 2018). Adanya media pembelajaran dapat memperlancar komunikasi dalam proses pembelajar(Arsyad \& Fatmawati, 2018; Taufiq et al., 2014). Media pembelajarana akan membuat pembelajaran lebih manarik (Rini et al., 2019). Media dapat memberikan pengalaman belajar yang bermakna, mengaktifkan dan menyenangkan anak (Andrijati, 2014), serta adanya media pembelajaran akan memberikan motivasi dalam proses pembelajaran (Aribowo, 2014). Media dapat dijadikan sebagai penghubung antara materi dan temuan alam dengan mencantumkan konten/gambar yang sesuai dengan materi, sehingga siswa lebih mudah untuk memahami materi serta mengingatnya (Zainorrahman et al., 2019). Jadi, adanya media pembelajaran sangat membatu proses pembelajaran. Pentingnya media pembelajaran akan menuntut Guru lebih kreatif dalam menggunakan media pembelajaran sehingga berdampak terhadap tercapainya tujuan pembelajaran. Namun analisis awal menujukkan hal yang berbeda dengan yang diinginkan dimana, permasalahan dalam pelajaran IPA yaitu dalam proses pembelajaran, siswa kurang aktif dan tidak memperhatikan penjelasan guru. Selain itu guru hanya menggunakan media pembelajaran yang berupa buku paket (Arip \& Aswat, 2021). Hal tersebut mengakibatkan tingkat pemahaman siswa terhadap muatan IPA menjadi rendah dan berdampak pada hasil belajar yang rendah pula. Buku pelajaran yang digunakan dalam pembelajaran kurang menarik karena hanya berisi banyak tulisan dan beberapa gambar serta bukunya tebal sehingga mempunyai kesan membosankan dan monoton. Buku pelajaran dengan tampilan yang cenderung kurang menarik, menyebabkan kurangnya minat siswa untuk membaca buku. Keadaan tersebut menunjukkan betapa pentingnya inovasi media pembelajaran untuk membuat siswa termotivasi untuk belajar sehingga dapat meningkatkan pengetahuan mereka. Kondisi ini tentunya berdampak hasil capaian pembelajaran yang diinginkan. Kondisi ini juga dialami di sekolah tempat observasi awal, dimana guru dala proses pembelajaran masih mengunkan media gambar serta kurangnya pemahaman teknologi yang dimiliki oleh guru, berdampak pada kurangnya kreatifitas guru dalam mengembangkan media pembelajaran. Selain itu, rendahnya kesadaran guru mengenai pentingnya penggunaan media pembelajaran dalam menunjang keberhasilan kegiatan pembelajaran. Kondisi ini bertampak terhadap ketercapaian KKM dalam proses pembelajaran dimana guru mengalami kesulitan saat memberikan pembelajaran kepada siswa dikarenakan kurang fokusnya mereka terhadap materi yang dijelaskan. Selain itu, berdasarkan hasil studi dokumentasi terdapat beberapa siswa yang belum mencapai nilai Kriteria Ketuntasan Minimal (KKM) pada nilai kompetensi pengetahuan IPA. Hal ini disebabkan karena media pembelajaran yang digunakan tidak sesuai dengan karakteristik siswa di kelas IV SD Negeri 6 Banyuning dan guru hanya menggunakan media gambar saat kegiatan pembelajaran. Jika, masalah ini dibiarakan tentunya akan mempengaruhi hasil belajar dan terwujudnya tujuan pembelajaran diinginkan.

Mengatasi masalah tersebut maka, perlu dikembangkan media yang sesuai dengan karakteritik peserta didik serta media mampu membuat siswa tertarik dan dapat meningkatkan hasil belajar siswa pada mata pelajaran IPA. Salah satu media pembelajaran yang bisa dikembangkan adalah media Pop-Up Book. Media pembelajaran Pop-Up Book adalah alat komunikasi yang menyampaikan pesan melalui gambar yang berunsur 3 dimensi yang menarik dan unik ketika bukunya dibuka (Rahmatilah et al., 2017). Selain itu, media Pop-Up Book merupakan sebuah buku yang bisa menampilkan halaman yang di dalamnya terdapat lipatan gambar yang membentuk tiga dimensi dan dapat digerakkan sehingga minat pembaca untuk membaca menjadi lebih meningkat (Sholikhah, 2017). Media pembelajaran Pop-Up Book 
dipandang dapat memberikan kesan yang dapat menarik perhatian siswa dan dapat menumbuhkan semangat belajar peserta didik (Karisma et al., 2020), membuat peserta didik lebih fokus mengamati materi yang tersedia pada Pop-Up Book (Wati \& Zuhdi, 2017), Penggunaan media Pop-Up Book yang berisi materi tentang kognitif diharapkan dapat meningkatkan kemampuan kognitif anak (Rahmawati \& Rukiyati, 2018). Kelebihan dari media pembelajaran Pop-Up Book yaitu dapat memberikan visualisasi cerita yang lebih menarik dikarenakan terdapat gambar berdimensi, menampilkan kejutan-kejutan dalam setiap halamannya, memperkuat pesan yang disampaikan dalam cerita, jenis kertas berwarna yang digunakan dapat menarik perhatian siswa dan tampilan visual yang lebih berdimensi membuat cerita semakin terasa nyata (Fadillah \& Lestari, 2016). Disamping itu, media Pop-Up Book ini dapat memberikan pengalaman khusus pada peserta didik karena melibatkan peserta didik seperti menggeser, membuka, dan melipat bagian Pop-Up Book (Putri et al., 2019). Hal ini akan membuat kesan tersendiri kepada pengguna sehingga akan lebih mudah masuk ke dalam ingatan ketika menggunakan media Pop-Up Book (Safri et al., 2017). Jabaran tersebut memberikan gabaran bahwa media Pop-Up Book efektif digunakan sebagai media pembelajaran dalam menunjang proses pembelajaran. Hal ini didukung oleh hasil penelitian yang menyatakan bahwa media pembelajaran Pop-Up Book yang dikembangkan efektif meningkatkan hasil belajar IPA (Diah et al., 2018; Elfiani et al., 2019). Penelitian yang menyatakan bahwa hasil validasi media Pop-Up Book yang dikembangkan sangat valid yang berarti sangat layak untuk digunakan sebagai media pembelajaran untuk kelas IV (Diah et al., 2018; Mustofa \& Syafi'ah, 2018; Oktaviarini, 2018). Berdasarkan hasil penelitian sebelumnya dapat disimpulkan bahwa media pembelajaran Pop-Up Book yang dikembangkan layak untuk diterapkan dalam menunjang proses pembelajaran di kelas. Media Pop-Up Book bisa menjadi solusi alternatif dalam mengatasi permasalahan dalam proses pembelajaran. Hal ini sesuai dengan hasil wawancara yang telah dilakukan dengan guru kelas IV yang menyatakan bahwa guru tersebut tidak pernah menggunakan media pembelajaran seperti media Pop-Up Book di dalam proses pembelajaran. Selain itu, guru tersebut juga menyatakan bahwa belum pernah mengembangkan dan membuat media pembelajaran Pop-Up Book dalam menyampaikan materi khususnya pelajaran IPA. Oleh karena itu, guru tersebut menyatakan sangat setuju jika materi IPA dikembangkan dalam bentuk media pembelajaran Pop-Up Book. Sehubungan dengan hal tersebut, maka perlu untuk dilakukan penelitian pengembangan media pembelajaran Pop-Up Book pada mata pelajaran IPA. Tujuan dari penelitian ini adalah untuk mendeskripsikan proses pengembangan media pembelajaran Pop-Up Book dan untuk mengetahui validitas hasil pengembangan media pembelajaran Pop-Up Book pada mata pelajaran IPA menurut review para ahli dan uji coba produk. Dengan menggunakan media pembelajaran Pop-Up Book pada mata pelajaran IPA dapat membuat siswa termotivasi untuk belajar dan memudahkan bagi siswa untuk memahami materi dan media ini dapat dimanfaatkan oleh guru sebagai media penyampaian materi pada mata pelajaran IPA. Selain itu, media pembelajaran Pop-Up Book ini dapat membuat pembelajaran di kelas menjadi lebih menarik, menyenangkan, dan kondusif.

\section{METODE}

Penelitian ini adalah penelitian pengembangan media pembelajaran Pop-Up Book mata pelajaran IPA Kelas IV yang menggunakan model ADDIE. Pemilihan model ini didasari atas pertimbangan bahwa model ini dikembangkan secara sistematis dan mudah dipahami. Menurut Branch (dalam Suryani et al., 2018:126), tahapan penelitian pengembangan model ADDIE, yaitu: Analisis (Analyze), Desain (Design), Pengembangan (Development), Implementasi (Implementation), dan Evaluasi (Evaluation). Desain tahapan penelitian pengembangan model ADDIE dapat ditunjukkan pada gambar 1. Pada tahap model ADDIE ini, terdapat dua tahapan yang tidak dapat dilaksanakan yaitu tahap implementasi dan evaluasi. Hal ini terjadi karena saat ini masih dalam masa pandemi sehingga harus mematuhi protokol kesehatan terkait dengan Covid-19. Tahap analisis (analyze) dilakukan untuk menganalisis masalah yang ada, menentukan tujuan pembelajaran, calon pengguna, mengidentifikasi sumber daya yang tersedia, dan menentukan sistem penyampaian yang potensial. Tahap desain dilakukan setelah tahap analisis selesai. Perancangan diawali dengan menentukan desain pada keseluruha Pop-Up Book yaitu mulai dari desain sampul depan dan belakang, desain gambar sesuai materi, dan menyusun materi dalam Pop-Up Book sampai ke pembuatan soal latihan. Dalam proses perancangan, media ini menggunakan program aplikasi Adobe Ilustrator dan Adobe Photoshop CS6. Rancangan Pop-Up Book yang telah selesai dibuat kemudian dikonsultasikan dengan dosen pembimbing untuk mendapatkan saran atau masukan, sehingga dapat dilaksanakan perbaikan. Tahap pengembangan dilakukan dengan mengembangkan Pop-Up Book sesuai dengan masukan dan saran dari dosen pembimbing. Setelah pengembangan Pop-Up Book selesai kemudian dilakukan uji validitas terhadap media yang dikembangkan. Uji Validitas didapatkan dari hasil review masing-masing ahli dan uji coba yaitu ahli isi materi pelajaran, ahli media pembelajaran, ahli 
desian pembelajaran, praktisi dan uji coba perorangan. Kemudian data hasil review dari ahli dan uji coba dianalisis dan dilakukan revisi sesuai dengan masukan dan saran dari ahli.

Subjek dalam penelitian ini yaitu media pembelajaran Pop-Up Book pada mata pelajaran IPA, sedangkan objek penelitian adalah validitas media pembelajaran Pop-Up Book. Pengumpulan data pada penelitian ini menggunakan metode kuesioner/angket yang digunakan untuk menilai kelayakan media pembelajaran Pop-Up Book yang meliputi ahli isi mata pelajaran, ahli media pembelajaran, ahli desain pembelajaran, ahli prakitis, dan uji coba perorangan. Data penelitian ini diperoleh dari dua jenis data, yaitu data kualitatif dan data kuantitatif. Data kualitatif diperoleh dari review ahli. Data tersebut dapat berupa tanggapan, masukan maupun kritikan, sedangkan data kuantitatif merupakan data berupa skor yang didapat dari lembar penilaian Pop-Up Book interaktif berdasarkan review uji ahli. Penyusunan instrumen dilakukan untuk menilai produk yang telah dikembangkan. Instrumen yang telah dibuat harus dilakukan uji validitas isi instrumen oleh pakar (judges). Uji validitas isi instrumen ini menggunakan rumus Gregory. Kuesioner yang diuji validitasnya yaitu kuesioner ahli isi mata pelajaran, ahli media pembelajaran, ahli desain pembelajaran, ahli praktisi, dan uji coba perorangan. Adapun hasil validasi instrumen yang telah diuji dapat disajikan pada Tabel 06. Berdasarkan hasil uji validitas isi menunjukkan bahwa validitas instrumen penilaian pada ahli isi mata pelajaran, ahli media pembelajaran, ahli desain pembelajaran, ahli praktisi, dan uji coba perorangan yaitu 1,00 yang menunjukkan validitas isi instrumen berada pada kategori validitas sangat tinggi sehingga instrumen tersebut valid dan bisa digunakan untuk memperoleh data

Metode dan teknik analisis data yang digunakan dalam penelitian ini yaitu analisis deskriptif kualitatif dan analisis deskriptif kuantitatif. Data kualitatif didapatkan dari hasil review uji ahli isi mata pelajaran, ahli media pembelajaran, ahli desain pembelajaran, ahli praktisi, dan uji coba perorangan. Data kualitatif berupa data yang disajikan dalam bentuk masukan, tanggapan, kritik dan saran atau perbaikan yang diperoleh dari review para ahli. Sedangkan data kuantitatif didapatkan dari hasil penilaian yang diperoleh dari lembar penilaian Pop-Up Book yang diisi oleh para ahli dan uji coba perorangan. Data analisis ini digunakan untuk mengolah dan menganalisis data berupa skor yang didapatkan dari pemberian kuesioner/angket dalam bentuk deskriptif presentase (Agung, 2014).

\section{HASIL DAN PEMBAHASAN}

\section{Hasil}

Penelitian ini dilaksanakan untuk mengembangkan media pembelajaran Pop-Up Book pada mata pelajaran IPA (Daur Hidup Hewan) yang sudah teruji validitasnya. Hasil penelitian ini diperoleh melalui tahap analisis, perancangan, pengembangan, serta validasi produk dilakukan oleh ahli isi mata pelajaran, ahli media pembelajaran, ahli desain pembelajaran, ahli praktisi, dan uji coba perorangan. Tahap analisis (analyze) dilakukan untuk menganalisis masalah yang ada, menentukan tujuan pembelajaran, calon pengguna, mengidentifikasi sumber daya yang tersedia, dan menentukan sistem penyampaian yang potensial. Hasil analisis masalah yang ada menunjukkan bahwa guru kelas IV menggunakan media pembelajaran saat proses pembelajaran namun pemilihan media tidak sesuai dengan karakteristik siswa. Selain itu, ditemukan kompetensi pengetahuan IPA siswa masih dibawah KKM, serta siswa kelas IV sangat membutuhkan media pembelajaran yang tepat. Dari masalah tersebut, hal ini dapat menimbulkan kejenuhan bagi siswa dan mengakibatkan siswa bosan, kurang semangat dan merasa tidak termotivasi saat mengikuti pembelajaran. Selaian itu berdasarakan analisis dalam menentukan tujuan pembelajaran dilakukan agar pemilihan tujuan pembelajaran selaras dengan tujuan pengembangan media pembelajaran. Tujuan pembelajaran ditentukan berdasarkan Kompetensi Inti (KI), Kompetensi Dasar (KD), dan Indikator. Berdasarkan hasil analisis, terdapat 3 tujuan pembelajaran yaitu Melalui mengamati gambar, peserta didik dapat menganalisis daur hidup dua makhluk hidup yang berbeda dengan tepat; Melalui mengamati gambar, peserta didik dapat menjelaskan daur hidup beberapa jenis makhluk hidup; dan Melalui mengamati gambar, peserta didik dapat menjelaskan upaya pelestarian hewan dengan tepat. Berdasarkan ketiga tujuan pembelajaran tersebut, dikembangkan materi IPA dengan topik "Daur Hidup Hewan". Dengan tujuan pembelajaran tersebut, pengembangan media pembelajaran bisa dikembangkan sesuai dengan materi.

Tahap perancangan (design) yang dilaksanakan dengan merancang Pop-Up Book yang diawali dengan menentukan materi yaitu Daur Hidup Hewan, dan mendesain sampul Pop-Up Book, background Pop-Up Book, gambar dan materi yang dicantumkan di dalam Pop-Up Book. Media Pop-Up Book Daur Hidup Hewan ini dirancang dengan menggunakan aplikasi program aplikasi Adobe Ilustrator dan Adobe Photoshop CS6 dengan kertas glossy ukuran A5. Rancangan Pop-Up Book ini selanjutnya dikonsultasikan dengan dosen pembimbing untuk memperoleh masukan dan saran, sehingga bisa melakukan suatu perbaikan. Setelah disetujui oleh dosen pembimbing kemudian dilanjutkan ke tahap pengembangan. 
Tahap pengembangan dilakukan dengan mengembangkan Pop-Up Book yang disesuaikan dengan desain yang telah dirancang dan sudah disetuji oleh dosen pembimbing. Media Pop-Up Book Daur Hidup Hewan dikembangkan dengan sampul depan dan belakang, prakata, daftar isi, kompetensi inti, kompetensi dasar, indikator, tujuan pembelajaran, petunjuk penggunaan Pop-Up Book, isi/materi yang dilengkapi dengan gambar yang menarik dan timbul, serta latihan soal. Tampilan media pembelajaran Pop-Up Book Daur Hidup Hewan yang dikembangkan dapat dilihat pada Gambar 02 dan Gambar 03. Setelah Media Pop-Up Book selesai dikembangkan, maka tahap selanjutnya yaitu melaksanakan uji validitas media Pop-Up Book Daur Hidup Hewan yang dikembangkan. Uji validitas media Pop-Up Book ini dilakukan oleh ahli isi mata pelajaran, ahli media pembelajaran, ahli desain pembelajaran, ahli praktisi, dan uji coba perorangan. Hasil validitas media pembelajaran Pop-Up Book Daur Hidup Hewan yang diperoleh dari ahli review dan uji coba perorangan disajikan pada Tabel 08. Hasil validasi diperoleh media pembelajaran Pop-Up Book pada mata pelajaran IPA (Daur Hidup Hewan) memperoleh kualifikasi yang sangat baik sesuai dengan acuan konversi skala lima dengan rentangan persentase 90\% - 100\%.

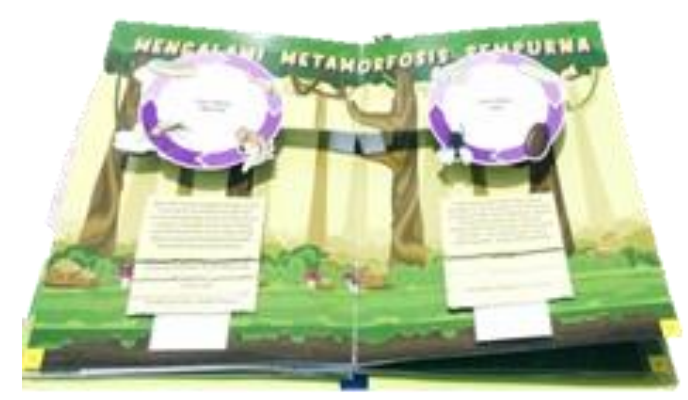

Gambar 1. Tampilan Pop-Up Book

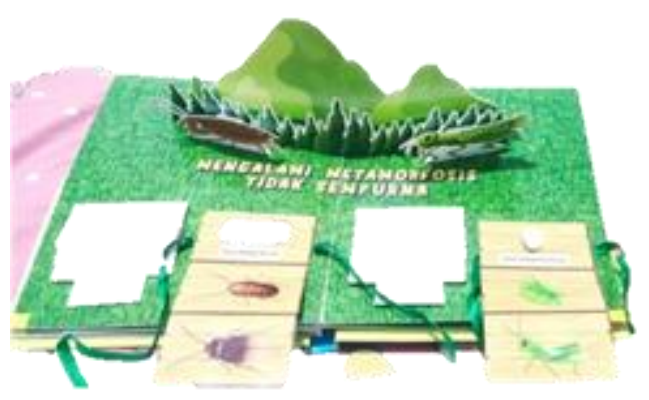

Gambar 2. Tampilan Pop-Up Book

Tabel 1. Hasil Uji Validitas

\begin{tabular}{clcl}
\hline No & \multicolumn{1}{c}{$\begin{array}{c}\text { Subjek uji coba } \\
\text { Pop-Up Book }\end{array}$} & Hasil Validitas (\%) & Keterangan \\
\hline 1 & Uji Ahli Isi Mata Pelajaran & $93,3 \%$ & Sangat baik \\
2 & Uji Ahli Media Pembelajaran & $95 \%$ & Sangat baik \\
3 & Uji Ahli Desain Pembelajaran & $95,3 \%$ & Sangat baik \\
4 & Uji Ahli Praktisi & $97,1 \%$ & Sangat baik \\
5 & Uji Coba Perorangan & $93,8 \%$ & Sangat baik \\
\hline
\end{tabular}

\section{Pembahasan}

Berdasarkan hasil analisis diperoleh bahwa diperlukan inovasi untuk mengatasi masalah dalam pembelajaran diperlukan suatu perantara untuk membantu siswa memahami materi terutama saat belajar di kelas. Perantara tersebut berupa penggunaan media pembelajaran Pop-Up Book. Penggunaan media pembelajaran Pop-Up Book yang dibuat dapat menarik perhatian siswa untuk mengikuti pembelajaran. Media pembelajaran Pop-Up Book adalah alat komunikasi yang menyampaikan pesan melalui gambar yang berunsur 3 dimensi yang menarik dan unik ketika bukunya dibuka (Fadiana \& Citra, 2020; Rahmatilah, \& Apriliya, 2017). Selain itu, media Pop-Up Book merupakan sebuah buku yang bisa menampilkan halaman yang di dalamnya terdapat lipatan gambar yang membentuk tiga dimensi dan dapat digerakkan sehingga minat pembaca untuk membaca menjadi lebih meningkat (Nazaruddin \& Efendi, 2018; Sholikhah, 2017). Media pembelajaran Pop-Up Book dipandang dapat memberikan kesan yang dapat menarik perhatian siswa dan dapat menumbuhkan semangat belajar peserta didik (Karisma et al., 2020), membuat peserta didik lebih fokus mengamati materi yang tersedia pada Pop-Up Book (Wati \& Zuhdi, 2017). Media Pop-Up Book merupakan buku cerita yang berbentuk tiga dimensi (3D) yang dapat menarik perhatian anak sehingga akan membuat anak menjadi penasaran tentang tampilan materi yang terdapat didalamnya(Ikbal \& Khuzaimah, 2020). Rasa penasaran anak biasanya ditunjukkan dengan berbagai ekspresi yang akan anak keluarkan seperti emosi takjub dengan mata melotot yang natural. Media Pop-Up Book sangat cocok digunakan untuk menciptakan suasana belajar yang bervariasi (Ningtiyas et al., 2019). Hal ini dapat membuat suasana pembelajaran menjadi menyenangkan. Dari hasil penilaian dapat dinyatakan bahwa media pembelajaran Pop-Up Book ini valid yang berarti layak digunakan untuk membantu guru dalam menyampaikan suatu materi dan mempermudah siswa dalam memahami materi serta menarik minat belajar peserta didik. Hal ini juga sejalan dengan teori perkembangan kognitif Piaget yang menyatakan bahwa anak usia sekolah dasar sudah mampu 
memecahkan masalah dan berfikir secara sistematis mengenai benda maupun contoh yang konkret, sehingga anak hanya mampu memecahkan masalah yang bersifat nyata atau diserap oleh panca indra mereka, bukan yang bersifat abstrak karena siswa akan mengalami kesulitan dalam menyelesaikan suatu permasalahan (Juwantara, 2019). Media Pop-Up Book memiliki fungsi untuk mengkonkretkan objek-objek yang abstrak(Sentarik \& Kusmariyatni, 2020). Dengan hal ini, media pembelajaran Pop-Up Book dapat membantu guru dalam memberikan contoh yang konkret tentang materi yang disampaikan.

Selain itu, Media pembelajaran Pop-Up Book Daur Hidup Hewan yang dikembangkan dan dirancang dengan menggunakan software aplikasi Adobe Ilustrator dan Adobe Photoshop CS6 dapat membantu guru dalam menyampaikan materi ataupun mempermudah siswa dalam memahami materi yang akan dipelajari. Hal ini diperkuat oleh Syofyan \& Sintra, (2020) yang menyatakan bahwa media PopUp Book dapat memudahkan siswa dalam menerima materi, menarik perhatian siswa dengan menggunakan gambar, warna yang ditampilkan, serta dapat menunjukkan fakta-fakta yang abstrak sehingga memperkuat kesan saat materi disampaikan. Disamping itu, Pop-Up Book menyajikan tampilan gambar yang membuat cerita atau materi yang disampaikan menjadi lebih menarik (Fadzilah et al., 2019). Media pembelajaran Pop-Up Book ini sangat mudah digunakan karena media yang dikembangkan dirancang untuk anak SD yang dibuat lebih sederhana sehingga mudah digunakan. Media yang dirancang harus mudah dilihat, menarik, sederhana, isinya bermanfaat, benar (dapat dipertanggungjawabkan), masuk akal dan tersusun dengan baik. Selain itu, tampilan media pembelajaran Pop-Up Book ini menarik serta sesuai dengan karakteristik siswa, gambar terlihat jelas dan pemilihan warna tidak berlebihan, teks di dalam media Pop-Up Book mudah untuk dibaca. Hal ini didukung oleh (Sudarma, 2015) yang menyatakan bahwa gambar akan terlihat jelas dan jenis warna yang ditampilkan jelas mempunyai maksud dan tujuan dalam komunikasi sesuai dengan fungsi informasi.

Hasil validitas media pembelajaran Pop-Up Book ini didukung oleh hasil penelitian yang menyatakan bahwa media pembelajaran Pop-Up Book yang telah dikembangkan dinyatakan sangat valid sehingga layak untuk digunakan sebagai media pembelajaran di dalam proses pembelajaran (Mustofa \& Syafi'ah, 2018; Oktaviarini, 2018). Penelitian yang menunjukkan bahwa media pembelajaran yang dikembangkan dinyatakan valid dan dapat digunakan sebagai media pembelajaran untuk siswa dalam kegiatan belajar untuk dapat meningkatkan hasil belajar IPA (Masturah et al., 2018). Berdasarkan hasil validitas media pembelajaran Pop-Up Book Daur Hidup Hewan dari para ahli review dan uji coba perorangan, menunjukkan bahwa media pembelajaran Pop-Up Book yang dikembangkan layak untuk digunakan sebagai media penyampaian materi di dalam proses pembelajaran. Dengan adanya penggunaan media pembelajaran Pop-Up Book ini, kompetensi pengetahuan IPA siswa menjadi meningkat dan juga siswa menjadi termotivasi serta semangat saat mengikuti pembelajaran di kelas.

\section{SIMPULAN}

Media pembelajaran Pop-Up Book Daur Hidup Hewan yang dikembangkan layak digunakan untuk menunjang proses pembelajaran pada mata pelajaran IPA (Daur Hidup Hewan). Media pembelajaran PopUp Book ini layak digunakan dilihat dari tampilan bentuk Pop-Up Book yang menarik, tampilan gambar yang menarik, kesesuaian materi dengan indikator pencapaian dan tujuan pembelajaran. Dengan pemanfaatan media pembelajaran Pop-Up Book ini secara optimal dapat membantu siswa untuk memahami materi dan meningkatkan nilai kompetensi pengetahuan IPA.

\section{DAFTAR PUSTAKA}

Agung, A. A. G. (2011). Metodologi Penelitian Pendidikan. Aditya Media Publishing.

Andrijati, N. (2014). Penerapan Media Pembelajaran Inovatif Dalam Pembelajaran Matematika Sekolah Dasar Di Pgsd Upp Tegal. Jurnal Penelitian Pendidikan, 31(2), 123-132. https://doi.org/10.15294/jpp.v31i2.5696.

Aribowo, E. K. (2014). Media Pembelajaran DIY: Membuat Flash Card dan Teka-Teki Silang Mandiri. Pembelajaran Bahasa Untuk Meningkatkan Kualitas Manusia Indonesia Yang Berkarakter Dalam Era Mondial, 1(July), 140-150. https://doi.org/10.6084/m9.figshare.6444407.

Arip, M., \& Aswat, H. (2021). Media Pop Up Book Untuk Meningkatkan Hasil Belajar Siswa Pada Mata Pelajaran IPA Di Sekolah Dasar. Edukatif: Jurnal Ilmu Pendidikan, 3(1), 261-268. https://doi.org/10.31004/edukatif.v3i1.329.

Arsyad, M. N., \& Fatmawati, F. (2018). Penerapan Media Pembelajaran Berbasis Multimedia Interaktif Terhadap Mahasiswa IKIP Budi Utomo Malang. Agastya: Jurnal Sejarah Dan Pembelajarannya, 8(2), 188. https://doi.org/10.25273/ajsp.v8i2.2702.

Bressington, D. T., Wong, W. kit, Lam, K. K. C., \& Chien, W. T. (2018). Concept mapping to promote 
meaningful learning, help relate theory to practice and improve learning self-efficacy in Asian mental health nursing students: A mixed-methods pilot study. Nurse Education Today, 60(February 2017), 47-55. https://doi.org/10.1016/j.nedt.2017.09.019.

Diah, M. E., Putrini, M. L. P., \& Simamora, A. H. (2018). Pengembangan Media Pembelajaran Pop-Up Book pada Mata Pelajaran IPA Kelas III Sekolah Dasar. Jurnal EDUTECH Universitas Pendidikan Ganesha, 6(2), 212-221. http://dx.doi.org/10.23887/jeu.v6i2.20294.

Elfiani, L., Taufik, M., \& Baiduri, B. (2019). The Development of Audio-Based Pop-Up Book Media on TwoDimensional Rectangular For Junior High School Students. Mathematics Education Journal, 3(1), 44. https://doi.org/10.22219/mej.v3i1.8420.

Fadiana, M., \& Citra, D. R. (2020). Peningkatan Rasa Percaya Diri Siswa Tunagrahita Melalui Pembelajaran Terintegrasi Semiotik Dengan Media Buku Pop Up. Dinamisia: Jurnal Pengabdian Kepada Masyarakat, 4(2), 373-383. https://doi.org/10.31849/dinamisia.v4i2.3940.

Fadillah, R. N. \& L. I. (2016). Buku Pop-Up Book untuk Pembelajaran Bercerita Siswa Sekolah Dasar. PERSPEKTIF Ilmu Pendidikan, 30(1), 21-26. https://doi.org/10.21009/PIP.301.3.

Fadzilah, F., Fatkhu Royana, I., \& Endah Handayani, D. (2019). Pengembangan Media Pop Up Book pada Pembelajaran Tema VI Cita-Citaku Subtema 1 Aku dan Cita-. Jurnal Penelitian Dan Pengembangan Pendidikan, 3(3), 223. https://doi.org/10.23887/jppp.v3i3.19258.

Ikbal, M. S., \& Khuzaimah, A. U. (2020). Pengembangan Modul Pembelajaran IPA Fisika Berbasis Pop-up Book. Jurnal Pendidikan Fisika, Volume 8(No 1), 53-60. http://journal.uinalauddin.ac.id/index.php/PendidikanFisika/article/view/12522.

Juniati, N. W., \& Widiana, I. W. (2017). Penerapan Model Pembelajaran Inkuiri Untuk Meningkatkan Hasil $\begin{array}{lllll}\text { Belajar Ipa. Journal of Education Action Research, 1(2), } 122 . & \end{array}$ https://doi.org/10.23887/jear.v1i2.12045.

Juwantara, R. A. (2019). Analisis Teori Perkembangan Kognitif Piaget Pada Tahap Anak Usia Operasional Konkret 7-12 Tahun dalam Pembelajaran Matematika. Jurnal Ilmiah Pendidikan Guru Madrasah Ibtidaiyah, 9(1), 27-34. https://doi.org/10.18592/aladzkapgmi.v9i1.3011.

Karisma, I. K. E., Margunayasa, I. G., \& Prasasti, P. A. T. (2020). Pengembangan Media Pop-Up Book pada Topik Perkembangbiakan Tumbuhan dan Hewan Kelas VI Sekolah Dasar. Jurnal Ilmiah Sekolah Dasar, 4(2), 121. https://doi.org/10.23887/jisd.v4i2.24458.

Kostiainen, E., Ukskoski, T., Ruohotie-Lyhty, M., Kauppinen, M., Kainulainen, J., \& Mäkinen, T. (2018). Meaningful learning in teacher education. Teaching and Teacher Education, 71, 66-77. https://doi.org/10.1016/j.tate.2017.12.009.

Kurniawati, I. D., \& Nita, S. (2018). Media Pembelajaran Berbasis Multimedia Interaktif Untuk Meningkatkan Pemahaman Konsep Mahasiswa. DOUBLECLICK: Journal of Computer and Information Technology, 1(2), 68. https://doi.org/10.25273/doubleclick.v1i2.1540.

Masturah, E. D., Mahadewi, L. P. P., \& ... (2018). Pengembangan Media Pembelajaran Pop-Up Book pada Mata Pelajaran IPA Kelas III Sekolah Dasar. Jurnal EDUTECH ..., 6, 212-221. https://ejournal.undiksha.ac.id/index.php/JEU/article/view/20294.

Mustofa, R., \& Syafi'ah, R. (2018). Pengembangan Media Pembelajaran Pop Up Book Materi Kenampakan Permukaan Bumi Mata Pelajaran IPA Kelas III SD. ELSE (Elementary School Education Journal), 2, 30-41. http://dx.doi.org/10.30651/else.v2i2.1723.

Nazaruddin, M. A., \& Efendi, M. (2018). The Book of Pop Up Augmented Reality to Increase Focus and Object Recognition Capabilities for Children with Autism. Journal of ICSAR, 2(1), 9-14. https://doi.org/10.17977/um005v2i12018p009.

Ningtiyas, T., Setyosari, P., \& Praherdiono, H. (2019). Pengembangan Media Pop-Up Book Untuk Mata Pelajaran Ipa Bab Siklus Air Dan Peristiwa Alam Sebagai Penguatan Kognitif Siswa. Jurnal Kajian Teknologi Pendidikan, 2(2), 115-120. https://doi.org/10.17977/um038v2i22019p115.

Oktaviarini, N. (2018). Pengembangan Media Pembelajaran Pop-Up Book Tema Pahlawanku pada Mata Pelajaran IPS Kelas IV SDN Kamulan 02 Kecamatan Talun Kabupaten Blitar. Jurnal Pena Sd, 03(02), 53-62. https://jurnal.stkippgritulungagung.ac.id/index.php/pena-sd/article/view/932.

Pendidikan, J., Indonesia, S., Safri, M., Sari, S. A., Studi, P., \& Kimia, P. (2017). Pengembangan Media Belajar Pop-Up Book Pada Materi Minyak Bumi. Jurnal Pendidikan Sains Indonesia (Indonesian Journal of Science Education), 5(1), 107-113. http://jurnal.unsyiah.ac.id/JPSI/article/view/8431.

Putra, P. (2017). Pendekatan Etnopedagogi Dalam Pembelajaran IPA SD/ MI. Primary Education Journal (PEJ), 1(17-23). http://pej.ftk.uinjambi.ac.id/index.php/PEJ/article/view/1.

Putri, Q. K., Pratjojo, P., \& Wijayanti, A. (2019). Pengembangan Media Buku Pop-Up untuk Meningkatkan Kemampuan Menyimak Tema Menyayangi Tumbuhan dan Hewan di Sekitar. Jurnal Pedagogi Dan Pembelajaran, 2(2), 169. https://doi.org/10.23887/jp2.v2i2.17905.

Rahmatilah, S., Hidayat, S., \& Apriliya, S. (2017). Media Pop-Up Book untuk Pembelajaran Bahasa 
Indonesia di Kelas Rendah. PEDADIDAKTIKA: Jurnal Ilmiah Pendidikan Guru Sekolah Dasar, 4(1), 139-148. https://ejournal.upi.edu/index.php/pedadidaktika/article/view/7302.

Rahmawati, D. I., \& Rukiyati, R. (2018). Developing Pop-Up Book Learning Media to Improve Cognitive Ability of Children Aged 4-5 Years. 249(Secret), 60-69. https://doi.org/10.2991/secret18.2018.10.

Rini, N. P., Shodiqin, A., \& Damayani, A. T. (2019). Keefektifan Model Pembelajaran ICM dan Bertukar Pasangan Berbantuan Media Kartu Angka terhadap Kemampuan Pemecahan Masalah Matematika. Jurnal Ilmiah Sekolah Dasar, 3(1), 1-9. https://doi.org/10.23887/jisd.v3i1.17173.

Sentarik, K., \& Kusmariyatni, N. (2020). Media Pop-Up Book pada Topik Sistem Tata Surya Kelas VI Sekolah Dasar. Jurnal Ilmiah Sekolah Dasar, 4(2), 197. https://doi.org/10.23887/jisd.v4i2.25135.

Sholikhah, A. (2017). Pengembangan Media Pop-Up Book untuk Meningkatkan Kemampuan Menulis Kreatif pada Mata Pelajaran Bahasa Indonesia Materi Menulis Karangan Kelas V SDN Rowoharjo Tahun Ajaran 2016/2017. Jurnal Simki-Pedagogia, 1(8), 1-8. http://simki.unpkediri.ac.id/mahasiswa/file_artikel/2017/5ee12721ce5cc0d9ddc2f1e33ed818c 3.pdf.

Sudarma, K. I, dkk. (2015). Desain Pembelajaran. Graha Ilmu.

Sugiarti, L., \& Handayani, D. E. (2017). Pengembangan Media Pokari Pokabu (Pop-Up dan Kartu Ajaib Pengelompokkan Tumbuhan) Untuk Siswa Kelas III SD/MI. Al Ibtida: Jurnal Pendidikan Guru MI, 4(1), 109. https://doi.org/10.24235/al.ibtida.snj.v4i1.1475.

Suryani, N., dkk. (2018). Media Pembelajaran Inovatif dan Pengembangannya. PT Remaja Rosdakarya.

Syawaludin, A., Gunarhadi, \& Rintayati, P. (2019). Enhancing elementary school students' abstract reasoning in science learning through augmented reality-based interactive multimedia. Jurnal Pendidikan IPA Indonesia, 8(2), 288-297. https://doi.org/10.15294/jpii.v8i2.19249.

Syofyan, H. (2020). Pengembangan Media Pop-Up Book. Jurnal Pendidikan Dasar, 11(2), 248-265. http://journal2.um.ac.id/index.php/jktp/article/viewFile/4551/3408.

Taufiq, M., Dewi, N. R., \& Widiyatmoko, A. (2014). Pengembangan media pembelajaran ipa terpadu berkarakter peduli lingkungan tema "konservasi" berpendekatan science-edutainment. Jurnal Pendidikan IPA Indonesia, 3(2), 140-145. https://doi.org/10.15294/jpii.v3i2.3113.

Tegeh, I. M., \& Kirna, I. M. (2010). Metode Pengembangan. Universitas Pendidikan Ganesha.

Wati, E. T., \& Zuhdi, U. (2017). Pengaruh Media Pop-Up Book terhadap Hasil Belajar Siswa Tema Ekosistem Kelas V SDN Karangpilang 1 Surabaya. JPGSD, 5(3), 913-923. https://doi.org/10.26618/jrpd.v2i2.2480.

Zainorrahman, Z., Azizah, L. F., \& Kadarisman, K. (2019). Pengembangan Media Berbasis Pop Up Book untuk Pembelajaran Ipa DI Mts Raudhatut Thalibin. Alpen: Jurnal Pendidikan Dasar, 2(2), 99-106. https://doi.org/10.24929/alpen.v2i2.21. 